\title{
ERYTHROCYTE SEDIMENTATION RATE: CAN BE A PROGNOSTIC MARKER IN ACUTE ISCHEMIC STROKE?
}

\author{
Selim Selçuk ÇOMOĞLU, Aslı Ece ÇíLLÍLER, Hayat GÜVEN
}

\author{
Dışkapı Yıldırım Beyazıt Research and Training Hospital Neurology Clinic, ANKARA
}

\begin{abstract}
OBJECTIVE: The aim of this study is to investigate the relationship between the erythrocyte sedimentation rate (ESR) values and the severity of neurological findings on admission, short- term prognosis, risk factors and etiology of the patients with acute ischemic stroke.

MATERIAL and METHODS: One hundred and fifty-eight consecutive patients who admitted to the hospital within 24 hours of stroke onset were retrospectively analyzed. National Institutes of Health Stroke Scale (NIHSS) and modified Rankin Scale (mRS) scores on admission and mRS scores at discharge, brain imaging findings, stroke etiology and risk factors of the patients were recorded. Patients were classified into three groups according to ESR values on admission and compared in terms of severity of clinical symptoms on admission, short-term prognosis, risk factors and etiology of stroke. RESULTS: A total 158 patients with acute ischemic stroke including 89 women and 69 men were enrolled in the study. Patients with ESR $\leq 10 \mathrm{~mm} / \mathrm{h}$ were included in group $1(\mathrm{n}=49)$, ESR levels between $11-25 \mathrm{~mm} / \mathrm{h}$ were included in group 2 $(n=69)$ and $E S R \geq 26 \mathrm{~mm} / \mathrm{h}$ were included in group $3(\mathrm{n}=40)$. No significant difference was determined between the groups in terms of NIHSS and mRS scores on admission and mRS scores at discharge and etiology of stroke. While coronary artery disease was found more frequently in group 1 and 2 than group $3(\mathrm{p}=0.018)$, valvular heart disease was more frequently in group 2 than group 1 ( $\mathrm{p}=0.037)$.

CONCLUSION: The results of our study revealed that ESR levels on admission do not reflect the severity of stroke and can not be accepted as a useful predictor of short-term prognosis in patients with acute ischemic stroke.

Key Words: Erythrocyte sedimentation rate, ischemic stroke, prognosis, cerebrovascular disease, inflammatory markers, inflammation.
\end{abstract}

\section{ERITTROSIT SEDIMENTASYON HIZI: AKUT İSKEMIK İNMEDE PROGNOSTIK BİR GÖSTERGE OLABILİR Mİ? ÖZET}

AMAÇ: Bu çalıșmada akut iskemik inmeli hastaların başvuru sırasındaki nörolojik bulgularının şiddeti, kısa dönem prognozları, inme risk faktörleri ve etyolojisi ile eritrosit sedimentasyon hızı (ESH) arasındaki ilişkinin değerlendirilmesi amaçlanmıştır.

GEREÇ ve YÖNTEM: İnme başlangıcından sonraki ilk 24 saatte hastaneye kabul edilen iskemik inmeli ardı sıra 158 hasta retrospektif olarak incelendi. Hastaların başvuru National Institutes of Health Stroke Skalası (NIHSS) ve modifiye Rankin Skalası (mRS) ve taburculuk modifiye Rankin Skalası (mRS) puanları, beyin görüntüleme bulguları, inme risk faktörleri ve etyolojileri kaydedildi. Hastaların başvuru sırasındaki ESH değerlerine göre 3 gruba ayrıldı ve bu 3 grupta yer alan hastalar başvuru nörolojik bulgularının şiddeti, kısa dönem prognozları, inme risk faktörleri ve etyolojileri açısından karşılaştırıldı.

BULGULAR: Seksen dokuz kadın, 69 erkek toplam 158 akut iskemik inmeli hasta çalışmaya alındı. ESH $\leq 10 \mathrm{~mm} / \mathrm{s}$ olan hastalar 1. grubu (n=49), ESH değerleri $11-25 \mathrm{~mm} / \mathrm{s}$ olanlar 2. grubu $(\mathrm{n}=69), \mathrm{ESH} \geq 26 \mathrm{~mm} / \mathrm{s}$ olan hastalar ise 3 . grubu $(n=40)$ oluşturdu. Gruplar arasında başvuru NIHSS ve mRS puanları, taburculuk mRS puanları ve inme etyolojileri açısından istatistiksel olarak anlamlı bir farklılık saptanmadı. Koroner arter hastalığı 1 ve 2. gruplarda 3. gruba göre istatistiksel olarak anlamlı olacak şekilde daha sık bulunurken ( $p=0.018)$, kalp kapak hastalığı 2. grupta 1. gruba göre daha sıktı ( $\mathrm{p}=0.037)$.

SONUÇ: Çalışmamızdan elde edilen bulgular, akut iskemik inmeli hastalarda ESH'nın başvuru klinik bulgularının şiddetini yansıtmadığını ve kısa-dönem prognozun öngörülmesinde bir belirteç olarak kullanılmasının yararlı olmadı̆̆ını göstermiştir.

Anahtar Sözcükler: Eritrosit sedimentasyon hızı, iskemik inme, prognoz, serebrovasküler hastalık, inflamatuvar belirteçler, inflamasyon.

Corresponding Author: Dr. Aslı Ece ÇiLLiER Dışkapı Yıldırım Beyazıt Research ve Training Hospital Neurology Clinic, Ankara, Turkey

E-mail: asliecetemel@yahoo.co.uk Phone: +903125962840

Received: 27.11.2012 Accepted: 12.01.2012 
This article should be cited as following: Çomoğlu S.S, Çillier A.E, Güven H. Erythrocyte sedımentation rate: can be a prognostic marker in acute ischemic stroke? Turkish Journal of Cerebrovascular Diseases 2013; 19 (1): 18-22. doi: 10.5505/tbdhd.2013.32042

\section{INTRODUCTION}

Inflammation plays an important role in the pathophysiology of the cerebral ischemia. Cerebral ischemia and consequential reperfusion initiate an inflammatory response in the brain which is associated with induction of several cytokines. Accompanying peripheral inflammatory response causes an increase in proinflammatory cytokines, leukocytes, platelets and acute-phase reactant proteins $(1,2)$. Elevation of fibrinogen and other acute-phase reactant proteins causes an increase in plasma viscosity and erythrocyte aggregation, hence reduces microcirculatory blood flow and promotes ischemia and infarction (1). Among acute-phase proteins, fibrinogen has the greatest effect on erythrocyte aggregation $(3,4)$. When blood flow is insufficient, increased erythrocyte aggregation and adhesiveness to the endothelium contribute vascular damage particularly in microcirculation $(4,5)$. Increased erythrocyte aggregation may also have an indirect role in the formation of arterial thrombosis through its effects on the platelets (4).

Erythrocyte aggregation can be evaluated indirectly by erythrocyte sedimentation rate (ESR) $(4,6)$. ESR is a simple, widely used and inexpensive laboratory test to assess an acute inflammatory response. Higher ESR values in acute phase of stroke may indicate a greater increase in fibrinogen concentration and blood viscosity, a more pronounced reduction in cerebral blood flow $(7,8)$. Clinical studies suggested that increased ESR levels are associated with poor clinical outcome, early clinical worsening, and extent of brain damage (9).

The present study aimed to investigate the relationship between the ESR values and the severity of neurological findings on admission, short-term prognosis, risk factors and etiology of stroke in acute ischemic stroke patients.

\section{MATERIAL AND METHODS}

One hundred and fifty-eight consecutive patients admitted to hospital within 24 hours of stroke onset were enrolled in the study retrospectively. All of the patients were evaluated by computed tomography (CT) or diffusionweighted magnetic resonance imaging (DWI).

Hematological and biochemical laboratory tests including ESR were performed in the first 24 hours. Electrocardiography, echocardiography and carotid-vertebral artery color Doppler ultrasonography were also performed. Risk factors for cerebrovascular disease such as hypertension, hypercholesterolemia, diabetes mellitus, coronary artery disease, atrial fibrillation, valvular heart disease, prior transient ischemic attacks and/or stroke were recorded. Systolic blood pressure 140 $\mathrm{mmHg}$ or higher, diastolic blood pressure $90 \mathrm{mmHg}$ or higher or both, was diagnosed as hypertension. Total cholesterol values $200 \mathrm{mg} / \mathrm{dl}$ or higher than $200 \mathrm{mg} / \mathrm{dl}$ were considered as hypercholesterolemia. The diagnosis of diabetes mellitus was confirmed with the use of antidiabetic agents prior to stroke or fasting blood glucose higher than $120 \mathrm{mg} / \mathrm{dl}$. The diagnosis of coronary artery disease, atrial fibrillation, valvular heart disease was confirmed with electrocardiography and echocardiography. Prior transient ischemic attacks and/or stroke were evaluated with brain CT and history of the patients. Patients were classified etiologically according to Trial of Org 10172 in Acute Stroke Treatment (TOAST) criteria. National Institutes of Health Stroke Scale (NIHSS) and modified Rankin Scale (mRS) scores on admission and mRS scores at discharge were recorded. Individuals with a history of infection on admission or within the last 7 days, having axillary body temperature higher than $37.5^{\circ} \mathrm{C}$ and accompanying acute coronary syndrome on admission were excluded from the trial.

In addition, patients with a history of malignancy, autoimmune and rheumatologic disease, recent operation or patients on steroid and regular anti-inflammatory agents were also excluded from the trial. Patients were divided into three groups according to their ESR values by using weighted averages. Severity of clinical symptoms on admission, short-term prognosis, risk factors and etiology of stroke were compared within groups.

Statistical analysis: Data analysis was performed using SPSS for Windows 11.5 packet program. Continuous variables were expressed as mean \pm standard deviation, ordinal variables were expressed as the median (minimum-maximum) and nominal variables were expressed in the form of the 
number of cases and percentage (\%). The ESR levels were divided into 3 groups using weighted averages. The significance of the difference between the groups in terms of averages was analyzed by one-way ANOVA. The significance of the difference in terms of median values was evaluated by Kruskal Wallis test. In case Kruskal Wallis test revealed significant results, nonparametric multiple comparison test was used in order to determine which group or groups cause the difference. Nominal variables were evaluated by Pearson chisquare test or Fisher's exact chi-square test. The results were considered significant for $\mathrm{p}<0,05$.

\section{RESULTS}

A total 158 patients with acute ischemic stroke including 89 women and 69 men were enrolled in the study. The mean duration of the patients' hospital stay was 8,96 days. The patients were divided into three groups according to ESR values. Patients with ESR $\leq 10 \mathrm{~mm} / \mathrm{h}$ were included in group $1(\mathrm{n}=49)$, ESR values between 11 and $25 \mathrm{~mm} / \mathrm{h}$ were included in group $2(n=69)$, and $E S R \geq 26$ $\mathrm{mm} / \mathrm{h}$ were included in group $3(\mathrm{n}=40)$.

Demographic characteristics of the patients and risk factors for stroke according to ESR values are shown in Table-1. Except for coronary artery disease and valvular heart disease, there was no statistically significant difference in terms of stroke risk factors between the groups. Coronary artery disease was found more frequently in group 1 and 2 than group $3(p=0.018)$ and valvular heart disease was more frequently in group 2 than group 1 $(\mathrm{p}=0.037)$.

Etiology of stroke, NIHSS and mRS scores on admission and mRS scores at discharge according to ESR values are shown in Table-2. Although large artery atherosclerosis is found to be more frequently than small vessel disease in higher ESR group, we couldn't detect any statistically significant differences between the groups in terms of stroke etiology. NIHSS and mRS scores on admission and mRS scores at discharge also showed no significant differences between the groups.

\section{DISCUSSION}

Higher ESR levels in the acute phase of stroke may indicate a greater increase in the concentration of fibrinogen and a more pronounced reduction in cerebral blood flow $(7,8)$. It was also reported that high ESR levels are associated with a larger infarct
Table 1. Demographic characteristics of the patients and risk factors for stroke.

\begin{tabular}{|c|c|c|c|c|}
\hline & $\begin{array}{c}\text { Group I } \\
(\mathrm{n}=49) \\
\text { ESR } \leq 10 \\
\mathrm{~mm} / \text { hour }\end{array}$ & $\begin{array}{c}\text { Group II } \\
(\mathrm{n}=69) \\
\text { ESR=11-25 } \\
\mathrm{mm} / \text { hour }\end{array}$ & $\begin{array}{c}\text { Group III } \\
(\mathrm{n}=40) \\
\mathrm{ESR} \geq 26 \\
\mathrm{~mm} / \text { hour }\end{array}$ & $\mathrm{p}$ \\
\hline Age & $66.7 \pm 10.6$ & $66.9 \pm 11.7$ & $67.8 \pm 10.7$ & $0.883^{*}$ \\
\hline Female gender & $22(44.9 \%)$ & $42(60.9 \%)$ & $25(62.5 \%)$ & $0.150^{\dagger}$ \\
\hline HT & $33(67.3 \%)$ & $49(71.0 \%)$ & $28(70.0 \%)$ & $0.911^{\dagger}$ \\
\hline DM & $11(22.4 \%)$ & $20(29.0 \%)$ & $15(37.5 \%)$ & $0.298^{+}$ \\
\hline $\mathrm{HC}$ & $24(49.0 \%)$ & $29(42.0 \%)$ & $17(42.5 \%)$ & $0.729^{\dagger}$ \\
\hline $\begin{array}{l}\text { Previous TIA } ₫ \\
\text { / stroke }\end{array}$ & $15(30.6 \%)$ & $19(27.5 \%)$ & $14(35.0 \%)$ & $0.716^{\dagger}$ \\
\hline $\begin{array}{l}\text { Coronary } \\
\text { artery disease }\end{array}$ & $21(42.9 \%) \ddagger$ & $23(33.3 \%) \S$ & $6(15.0 \%) \neq \S$ & $0.018^{\dagger}$ \\
\hline $\begin{array}{l}\text { Valvular heart } \\
\text { disease }\end{array}$ & $1(2.0 \%) \|$ & $10(14.5 \%) \|$ & $5(12.5 \%)$ & $0.037^{\dagger}$ \\
\hline $\mathrm{AF}$ & $10(20.4 \%)$ & $16(23.2 \%)$ & $4(10.0 \%)$ & $0.228^{\dagger}$ \\
\hline \multicolumn{5}{|c|}{$\begin{array}{l}\text { *One way ANOVA } \\
\text { †Pearson Chi-square test. } \\
\text { ‡The difference between the Group I and Group III is statistically significant }(\mathrm{p}=0,004) \text {. } \\
\text { §The difference between the Group II and Group III is statistically significant }(\mathrm{p}=0,037) \text {. } \\
\text { I The difference between the Group I and Group II is statistically significant }(\mathrm{p}=0,025) \text {. } \\
\text { ๆ Transient ischemic attack }\end{array}$} \\
\hline
\end{tabular}

Table 2. Etiology of stroke, NIHSS and mRS scores on admission and $\mathrm{mRS}$ scores at discharge.

\begin{tabular}{|c|c|c|c|c|}
\hline & $\begin{array}{c}\text { Group I } \\
(\mathrm{n}=49) \\
\text { ESR } \leq 10 \\
\mathrm{~mm} / \text { hour }\end{array}$ & $\begin{array}{c}\text { Group II } \\
(\mathrm{n}=69) \\
\text { ESR=11-25 } \\
\mathrm{mm} / \text { hour }\end{array}$ & $\begin{array}{c}\text { Group III } \\
(\mathrm{n}=40) \\
\mathrm{ESR} \geq 26 \\
\mathrm{~mm} / \text { hour }\end{array}$ & $\mathrm{p}$ \\
\hline \multicolumn{5}{|l|}{$\begin{array}{l}\text { Etiology of } \\
\text { stroke }\end{array}$} \\
\hline $\begin{array}{l}\text { Large-artery } \\
\text { atherosclerosis }\end{array}$ & $12(24.5 \%)$ & $18(26.1 \%)$ & $14(35.0 \%)$ & $0,497^{\dagger}$ \\
\hline $\begin{array}{l}\text { Small-vessel } \\
\text { occlusion }\end{array}$ & $13(26.5 \%)$ & $18(26.1 \%)$ & $7(17.5 \%)$ & $0,532^{+}$ \\
\hline $\begin{array}{l}\text { Cardio- } \\
\text { embolism }\end{array}$ & $18(36.7 \%)$ & $26(37.7 \%)$ & $12(30.0 \%)$ & $0,703^{+}$ \\
\hline $\begin{array}{l}\text { Other } \\
\text { determined } \\
\text { etiology }\end{array}$ & $1(2.0 \%)$ & - & - & - \\
\hline $\begin{array}{l}\text { Undetermined } \\
\text { etiology }\end{array}$ & $5(10.2 \%)$ & $7(10.1 \%)$ & $7(17.5 \%)$ & $0,468^{\dagger}$ \\
\hline $\begin{array}{l}\text { NIHSS scores } \\
\text { on admission }\end{array}$ & $4(1-17)$ & $5(1-15)$ & $5,5(1-13)$ & $0,550^{* *}$ \\
\hline $\begin{array}{l}\text { mRS scores on } \\
\text { admission }\end{array}$ & $3(2-6)$ & $3(1-6)$ & $4(1-6)$ & $0,535^{* *}$ \\
\hline $\begin{array}{l}\text { mRS scores at } \\
\text { discharge }\end{array}$ & $3(0-7)$ & $3(0-6)$ & $4(1-6)$ & $0,889^{* *}$ \\
\hline
\end{tabular}

**Kruskal Wallis test

volume (10-12) and a poor outcome $(7,8,10,11,13$ 15). However, neither the NIHSS and mRS scores on admission nor the mRS scores at discharge had any association with the ESR levels in patients with acute stroke in our study. Also, there was no correlation between ESR levels and stroke etiology and risk factors except for coronary artery disease and valvular heart disease.

In the previous studies, ESR levels were found to be increased in the acute phase of stroke $(4,8,11,12,16)$ and associated with short-term poor prognosis $(7,11)$. It was also reported that high ESR levels in the acute phase of stroke are associated with long-term poor outcome, but not with short- 
term outcome $(10,13)$. Although a positive correlation was demostrated between higher ESR levels and 30-day mortality rates $(14,15)$, others didn't found any relationship $(17,18)$. Because of early clinical deteoriation and elevated D-dimer levels in acute stroke patients with high ESR levels, it was suggested that high ESR levels may be an indicator of ongoing thrombosis $(7,19)$. In addition, high ESR levels were defined as a useful marker for identifying patients at risk for progression of atherosclerosis in ischemic stroke (20).

In the present study, high ESR levels were not found as a predictive marker for the prognosis of acute stroke patients. This may be related with the fact that ESR is a nonspecific marker of infection and inflammation (3). ESR is found to be elevated in many acute and chronic diseases characterized by tissue necrosis and inflammation $(3,6)$. On the other hand, ESR is an indirect method to reveal red blood cell aggregation (21) and poorly correlates with erythrocyte aggregation because of the confounding effects of hematocrit, plasma albumin levels, temperature and hemodilution with anticoagulants (4). In a study using a simple slide test and image analysis for the direct measurement of erythrocyte adhesiveness/aggregation, highly significant difference was noted between patients with TIA or ischemic stroke and controls, although there was no significant difference for both ESR or fibrinogen concentrations (21). Besides, epidemiologic studies have also shown that there is a wide variation of inflammatory, haemostatic and rheologic variables within the general population.

Such variations in markers of low-grade inflammation are associated with genetic and familial influences, age, enviromental stresses, cardiovascular risk factors and vascular or nonvascular diseases (1). Another possible reason detecting ESR as a non-valuable marker in our study may be related to timing of either ESR measurement or assessment of prognosis. We focused on ESR values during admission; consecutive peak values following the insult might be even more informative. On the other hand, preferring relatively long-term outcome scores might influence our results instead of using discharge scores to evaluate the prognosis.

It has been found that markers of inflammation are associated with future coronary heart disease rates in the prospective population studies $(1,6,22)$. It was interesting to observe that coronary artery disease had been detected less frequently in the higher ESR group as compared with other groups. This finding may be assumed as ESR is not a predictive marker for both coronary artery disease and ischemic stroke. On the other hand, valvular heart disease was found to be less frequently in the first group having lower ESR levels compared with group 2. It is consistent with the fact that valvular heart disease is characterized by ongoing inflammatory response (23).

Although it was observed that large artery disease occurs more frequently than small vessel disease in the higher ESR group, we couldn't found any statistically significant differences among ESR groups in terms of stroke etiology. In a study evaluating the association of subtypes of inflammatory markers with vascular disease in patients with acute ischemic stroke, no correlation was found between ESR levels and large or small vessel disease (24). However, it was reported that patients with atherothrombotic stroke showed raised fibrinogen and ESR, while cardioembolic stroke patients had increased D-dimer, fibrinogen and D-dimer/fibrinogen ratio. They suggested that the biochemical profile may be prothrombotic in patients with cardioembolism and inflammatory in those with atherothrombotic stroke (25).

The present study revealed that ESR levels are not specific enough to predict the prognosis of patients with acute ischemic stroke and using more specific inflammatory markers for early identification of prognosis in the acute phase of stroke may be even more informative.

\section{REFERENCES}

1. Lowe GD. Circulating inflammatory markers and risks of cardiovascular and non-cardiovascular disease. J Thromb Haemost 2005; 3(8): 1618-27.

2. Rodriguez-Yáñez M, Castillo J. Role of inflammatory markers in brain ischemia. Curr Opin Neurol 2008; 21(3): 353-7.

3. Saadeh $C$. The erythrocyte sedimentation rate: old and new clinical applications. South Med J 1998; 91(3): 220-5.

4. Lakshmi AB, Uma P, Venkatachalam Ch, Nageswar Rao GS. A simple slide test to assess erythrocyte aggregation in acute STelevated myocardial infarction and acute ischemic stroke: its prognostic significance. Indian J Pathol Microbiol 2011; 54(1): 63-9.

5. Minetti M, Agati L, Malorni W. The microenvironment can shift erythrocytes from a friendly to a harmful behavior: pathogenetic implications for vascular diseases. Cardiovasc Res 2007; 75(1): 21-8.

6. Andresdottir MB, Sigfusson N, Sigvaldason H, Gudnason V. Erythrocyte sedimentation rate, an independent predictor of coronary heart disease in men and women: The Reykjavik Study. Am J Epidemiol 2003; 158 (9): 844-51.

7. Chamorro A, Vila N, Ascaso C, et al. Early prediction of stroke 
severity. Role of the eryhtrocyte sedimentation rate. Stroke 1995; 26(4): 573-6.

8. Nayak AR, Kashyap RS, Kabra D, et al. Evaluation of routinely performed hematological and biochemical parameters for the prognosis of acute ischemic stroke patients. Neurol Sci 2011; 32(5): 855-60.

9. Chamorro A. Role of inflammation in stroke and atherothrombosis. Cerebrovasc Dis 2004; 17: 1-5.

10. Smith CJ, Emsley HC, Gavin CM, et al. Peak plasma interleukin- 6 and other peripheral markers of inflammation in the first week of ischaemic stroke correlate with brian infarct volume, stroke severity and long-term outcome. BMC Neurol 2004; $4: 2$.

11. Balestrino M, Partinico D, Finocchi C, Gandolfo C. White blood cell count and erythrocyte sedimentation rate correlate with outcome in patients with acute ischemic stroke. J Stroke Cerebrovasc Dis 1998; 7(2): 139-44.

12. Zaremba J, Skrobański P, Losy J. Acute ischemic stroke increases the eryhtrocyte sedimentation rate, which correlates with early brain damage. Folia Morphol (Warsz) 2004; 63(4): 373-6.

13. Anuk T, Assayag EB, Rotstein R, et al. Prognostic implications of admission inflammatory profile in acute ischemic neurological events. Acta Neurol Scand 2002; 106(4): 196-9.

14. Czlonkowska A, Ryglewicz D, Lechowicz W. Basic analytical parameters as the predictive factors for 30 -day case fatality rate in stroke. Acta Neurol Scand 1997; 95(2): 121-4.

15. Bhatia RS, Garg RK, Gaur SP, et al. Predictive value of routine hematological and biochemical parameters on 30-day fatality in acute stroke. Neurol India 2004; 52(2): 220-3.

16. Emsley HC, Smith CJ, Gavin CM, et al. An early and sustained peripheral inflammatory response in acute ischaemic stroke: relationships with infection and atherosclerosis. J Neuroimmunol 2003; 139(1-2): 93-101.
17. Szczudlik A, Slowik A, Turaj W, et al. Early predictors of 30day mortality in supratentorial ischemic stroke patients-first episode. Med Sci Monit 2000; 6(1): 75-80.

18. Zuliani G, Cherubini A, Ranzini M, et al. Risk factors for shortterm mortality in older subjects with acute ischemic stroke. Gerontology 2006; 52(4): 231-6.

19. Swartz JE, Jacobson BF, Connor MD, et al. Erythrocyte sedimentation rate as a marker of inflammation and ongoing coagulation in stroke and transient ischaemic attack. S Afr Med J 2005; 95(8): 607-12.

20. De Silva DA, Woon FP, Gan HY, et al. Arterial stiffness is associated with raised levels of the inflammatory marker erythrocyte sedimentation rate among ischaemic stroke patients. Intern Med J 2008; 38(12): 918-20.

21. Zeltser D, Bornstein NM, Rotstein R, et al. The erythrocyte adhesiveness/aggregation test in the peripheral blood of patients with ischemic brain events. Acta Neurol Scand 2001; 103(5): 316-9.

22. Koenig W, Rosenson RS. Acute-phase reactants and coronary heart disease. Semin Vasc Med 2002; 2(4) : 417-28.

23. Moura LM, Rocha-Gonçalves F, Zamorano JL, et al. New cardiovascular biomarkers: clinical implications in patients with valvular heart disease. Expert Rev Cardiovasc Ther 2008; 6(7): 945-54.

24. Suwanwela NC, Chutinet A, Phanthumchinda K. Inflammatory markers and conventional atherosclerotic risk factors in acute ischemic stroke: comparative study between vascular disease subtypes. J Med Assoc Thai 2006; 89(12): 2021-7.

25. Alvarez-Perez FJ, Castelo-Branco M, Alvarez-Sabin J. Usefulness of measurement of fibrinogen, D-dimer, D-dimer/ fibrinogen ratio, $C$ reactive protein and erythrocyte sedimentation rate to assess the pathophysiology and mechanism of ischaemic stroke. J Neurol Neurosurg Psychiatry 2011; 82(9): 986-92. 